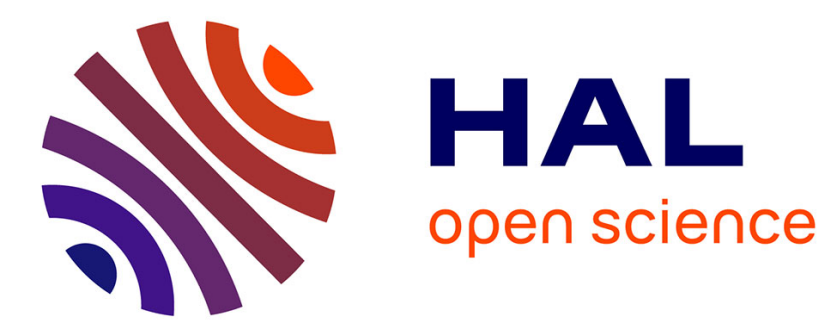

\title{
Saidabad, Pretoria, Sarajevo, The Hague, Brussels: conflicts and cooperation in security and policing
}

Nicholas Dorn, Tom Vander Beken

\section{To cite this version:}

Nicholas Dorn, Tom Vander Beken. Saidabad, Pretoria, Sarajevo, The Hague, Brussels: conflicts and cooperation in security and policing. Crime, Law and Social Change, 2008, 51 (2), pp.205-209. 10.1007/s10611-008-9158-9 . hal-00478398

\section{HAL Id: hal-00478398 https://hal.science/hal-00478398}

Submitted on 30 Apr 2010

HAL is a multi-disciplinary open access archive for the deposit and dissemination of scientific research documents, whether they are published or not. The documents may come from teaching and research institutions in France or abroad, or from public or private research centers.
L'archive ouverte pluridisciplinaire HAL, est destinée au dépôt et à la diffusion de documents scientifiques de niveau recherche, publiés ou non, émanant des établissements d'enseignement et de recherche français ou étrangers, des laboratoires publics ou privés. 


\title{
Saidabad, Pretoria, Sarajevo, The Hague, Brussels: conflicts and cooperation in security and policing
}

\author{
Nicholas Dorn • Tom Vander Beken
}

Published online: 21 October 2008

(C) Springer Science + Business Media B.V. 2008

Syncrisis - a term from Socrates we take up from the authors of the first paper in this special issue of CLSC-means bringing together ideas and practices that are different and possibly incomparable. Socrates saw this as a method of social enquiry: the reactions or resonances created by the juxtaposition could be examined in order to understand present situations and possibilities for change. Another of Socrates' techniques was anacrisis, meaning luring one's interlocutors (or maybe oneself) into making explicit one's otherwise hidden and taken-for-granted assumptions - in other words, surfacing deep assumptions as explicit propositions. Such approaches underpin much of contemporary argument and evidence-seeking in the social sciences generally and in criminology specifically [1]. Through alternative modes of enquiry such as these criminologists construct a dialogue in which current conditions are examined and various ways forward envisaged [5].

For this special issue, the editors commissioned a series of papers on developments in justice systems and policing internationally - in some regions of the world that are deeply conflict-riven, uneasily 'post-conflict', or relatively peaceful. The contributors report from Afghanistan, the Balkans, South Africa and the European Union. They variously proceed through syncrisis, in relation to some seemingly 'stuck' conflicts around different social meanings and institutions of justice (as explored below in relation to Afghanistan), or proceed through anacrisis, getting close to one particular social actor (in relation to the international police mission in Bosnia and Herzegovina). What could be learnt in general terms from the papers as a whole and from their juxtaposition? One thing that is quite striking is that

\footnotetext{
N. Dorn $(\bowtie)$

Criminology Department, School of Law, Erasmus University Rotterdam, Rotterdam, The Netherlands e-mail: dorn@law.eur.nl

N. Dorn

Cardiff University, Cardiff, UK

T. Vander Beken

Institute for International Research on Criminal Policy, Ghent University, Ghent, Belgium
} 
more consideration is given to broad political and cultural factors in the more conflict-riven situations (Afghanistan and, to some extent still, the Balkans). The closer one moves to militarily and politically settled regions such as the European Union, the tighter is the analytical focus upon middle-range, institutional or technical factors on police and judicial cooperation. A confrontation between opposites provokes a broader analysis than an engagement with specifics.

The first contribution, Negotiating justice sector reform in Afghanistan, by Astri Suhrke and Kaja Borchgrevink, brings out the differences between two quite distinct institutions of justice in Afghanistan. Westernised concepts and practices, imposed from the top down, fail to displace traditional and deeply socially embedded, locally-mediated practices, which have roots both in Islam generally and in Afghan society more specifically. In approaching this topic, we may comment that there is no reason to expect all 'legal transplants' to fail: consideration of the rich history of international legal borrowings suggests otherwise [4]. However, local consent may be an important success factor. Accordingly, whether driven by western notions of a legal void in Afghan society or by a desire to counter existing practices, western and Afghan government attempts to restructure traditional justice practises have had little success so far, as Suhrke and Borchgrevink show us. The authors also give a description of how local, tradition-based justice works, at least in some rural areas. Their account does not envisage success for attempts to bypass, overcome or ignore these specifically Afghan traditions and their wider Islamic basis. Western 'help' might be more readily seen in such terms if it were more willing to take its point of departure what the mullahs describe as Afghiyat and Islanijat. To many readers, this will seem to be in line with what we already know more generally about development processes, social institutions and justice reform - whilst for some other observers it may remain too bitter a pill to swallow. Syncrisis, indeed!

The second contribution, Becoming 'European' through police reform: A successful strategy in Bosnia and Herzegovina?, on police reform in a post-crisis region, the western Balkans, describes a region in which the political and economic puissance of western intervention is sufficient to overlay, but not to transform (and certainly not revitalise) existing institutions of justice. Police and judicial 'reform' has been a mantra of democratisation and progress in former Yugoslavia [8]. The paper by Gemma Collantes Celador presents a close-up study of police reform in Bosnia and Herzegovina $(\mathrm{BiH})$. It seems that the reforms, instituted over a decade or so, remain of a rather technical nature; there is little evidence of transformation of the institutions and occupational culture of the police. Moreover the UN and EUsponsored reforms, at the time of writing, have contributed little to wider political transformation of $\mathrm{BiH}$, from a fragmented country to a more integrated one. Progress in police reform can be found in terms of numbers of police undergoing training and similar intermediate indicators. One can add that the wider governance context of all this - the over-arching role and powers of the High Representative-provides a 'sticks and carrots' form of incentives system, or conditionality as it often called, without inspiring true local 'ownership' or political breakthroughs. The quality of historically bequeathed judicial and policing traditions has been eclipsed by the civil war in Yugoslavia and by characterisation in terms of 'corruption'. The situation is further made complicated by the fact that the EU Police Mission (EUPM), like many international missions, has a rather dispersed quality: it is staffed by nationals from 
all EU Member States. Such missions themselves lack what they aim to impart-a cohesive culture. Here we see a bit of a muddle, the hand of friendship is there, but one is distracted from it by the equally present hand of compulsion, not to mention what must be a rather baffling gesturing of so many hands. This is by no means an attempted policy implant, since that would imply coherence of the thing being offered. Criminology may need new language to grasp such situations. Celador generates a sketch that is in some ways as depressing, or possibly more depressing than given of Afghanistan, since one sees no vibrant alternative waiting in the wings.

The contribution of Elrena van der Spuy Police Cooperation in the Southern African region: politics and practicalities looks at a region in which armed conflict was sustained over a longer period, being sustained by the Cold War and by Apartheid. She writes that the substantial realignment of foreign relations of the fourteen Southern African Development Community (SADC) member states in support of economic, political and security cooperation produced a new doctrine of military cooperation and created a vision of collaborative peace-keeping and of police cooperation [7]. Despite some (relatively limited) assistance on policing from countries outside the region, and cooperation in the wider context of international policing (through Interpol, for example), the focus of police cooperation in Southern Africa is on relations between police agencies within the region (a big difference from the international direction in $\mathrm{BiH}$, above). However there is one 'first amongst equals' in the region, and van der Spuy refers to the 'police agency of the regional hegemon, South Africa' as playing a 'strategic role in cooperation and development of sister organisations', in particular through the Southern African Regional Police Chiefs Coordination Committee. It is interesting therefore to read her account alongside that provided by Collantes about $\mathrm{BiH}$; the big difference of course is that South Africa influences, rather than imposes conditionality upon, its partners. The author outlines the structures and processes through which regional police cooperation is attempted, and fills out the picture by exploring examples in relation to destruction of weapons, 'organised crime', democratic policing, policing illegal immigration, peace-keeping and the policing of big events. Her conclusion (wary, perhaps, but more optimistic than those arrived at in some other contributions to this special issue) is that some distance has yet to be travelled before the region can arrive at a robust security cooperation framework.

All of which brings us to questions about police cooperation within the European Union. Europol has been widely commented upon in the criminological and other literatures, sometimes sympathetically as part of an analysis of the evolution of the EU [6], and sometimes from a critical perspective on shortfalls in human rights in relation to policing, intelligence, data protection, immigration and anti-terrorist measures [2]. This special issue rounds off with two contributions on Europol. First, Petrus van Duyne and Tom Vander Beken criticise Europol's intelligence model from a methodological point of view. The core proposition of their paper, The incantations of the EU organised crime policy making, involves comparing and counter-posing police intelligence systems and social science research. They query the agency's manner of integrating and interpreting a wide mix of inputs from different countries, sectors of the economy and social groups, sifted through police information recording practices and technical systems, finally being drawn together into an annual Organised Crime Threat Assessment (OCTA, previously Organised 
Crime Situation Report or OCSR). The authors give a historical description of some national and EU-level development in the origins and conduct of this exercise, then develop their critique of the methodological basis of the most recent versions of the report. The background here is that one of the authors requested Europol to supply him with a paper on their OCTA methodology; Europol declined on the grounds that knowing how it put together its overview might somehow aid criminals. However the Dutch government was more amenable and gave the information requested (or at least a version thereof - not a trivial point, since one question is how stable the methodology is over time). Van Duyne and Vander Beken characterise the obtained document as unconvincing in methodological terms. This criticism might imply an assumption that police agencies should do as social scientists would (although perhaps agreement on that position might not end the debate, since variations might be found amongst criminologists and other researchers when it comes to matters such as core assumptions, methods, basis for interpretation, and presentation). This contribution raises many questions about truth claims, the purpose of information for policy making in the arena of police and judicial matters, and about the politics of interpretation when trying to integrate information from diverse sources (cultures, technical systems, gatekeepers, private sector contributors, academic commentators, police practitioners and policy stakeholders).

For the future, could the world live without 'organised crime'? Drawing upon European policy changes that were proposed in 2006, politically agreed in 2008 and will take effect from 2010, Nicholas Dorn's contribution on The end of organised crime in the European Union seizes upon some possible implications of the change in the legal competency of Europol, from targeting 'organised crime' to speaking instead of 'serious crimes'. This definitional and tasking change occurs in the context of institutional changes in the legal status of Europol, from an inter-state organisation to an agency more firmly integrated in the EU, funded from the general EU budget and (somewhat) answerable to the European Parliament. He asks whether the new European agenda on 'serious' crime is at all significant and why is it coming to the fore now, after all the years in which 'organised crime' (OC) has been such a mantra in international policing circles (not to mention popular media). The author suggests that there is indeed something at stake, which must be of considerable interest for those arguing in favour of a criminology of 'social harms' and safety, in place of a criminology of the other (threat, insecurity, etc.). Dorn discusses aspects of some EU Member State's historical and contemporary attachment to ' $\mathrm{OC}$ ' as a definitional and motivational policy motif, which has now been undermined. Maybe, somewhat ironically, 'OC' simply is not 'needed' so much today, now that we have terrorism. This might open up the possibility of a harm-based framework for police cooperation on serious crime (which might conceivably provide part of the clearlyneeded new approach for defining and managing terrorism?). There would however still be quite some way to go.

What overall conclusions, if any, might arrived at on the basis of these diverse contributions? One overall impression is of the vibrancy and width of issues tackled by those writing on judicial and policing developments in conflict zones and postconflict zones: the more the debate is polarised by parties who are actually at war, or recently were, the greater the attention to broad structural, political and cultural issues. The editors themselves, sitting in Europe, note with some chagrin the 
relatively restricted scope of debates on police and judicial matters in Europe: note to teacher, must try harder. In summing up, they refer to a stock questions on the relationship between social science and policy: who leads, if either? For Socrates, as for contemporary criminologists, there must at least be a healthy distance between policy makers and critical intellectuals. That alone however hardly guarantees the quality of intellectual thought. Historical myth has it that the Oracle at Delphi gave an opinion that Socrates was the brightest fellow of his time (here it must be remembered that Oracles speak more about the future than the past or present [3]). Flattered but incredulous, Socrates embarked on a series of discussions with his peers, seeking criteria and to unearth others with a stronger claim. Finding none, he felt obliged to agree with the Oracle. He went on to enlighten his contemporaries and to infuriate policy makers - eventually being sentenced to death by drinking hemlock. This is a fate unlikely to followed by many western criminologists, even those who appear somewhat Socratic in some other respects. However, activism on matters of judicial and police reform can indeed be fatal in contexts such as Afghanistan. We owe a duty to deepen our analyses both home and abroad, this special collection being a modest step in this direction.

\section{References}

1. Beirne, P. (1983). Cultural relativism and comparative criminology. Crime, Law and Social Change, 7 (4), 371-391.

2. Den Boer, M., Hillebrand, C., \& Nolke, A. (2008). Legitimacy under pressure: the European web of counter-terrorism networks. Journal of Common Market Studies, 46(1), 101-124.

3. Dorn, N., \& Levi, M. (2006). From Delphi to Brussels, the policy context: prophecy, crime proofing, assessment. European Journal on Criminal Policy and Research, 12(3-4), 213-220 December.

4. Nelken, D. (2002). Comparing criminal justice. In M. Maguire, R. Morgan, \& R. Reiner (Eds.), Oxford Handbook of Criminology. Oxford: Oxford University Press.

5. Sheptycki, J., \& Wardak, A. (2005). Transnational and Comparative Criminology. London: Routledge Cavendish.

6. Storbeck, J. (2003). The European Union and enlargement: challenge and opportunity for Europol in the fight against international crime. European Foreign Affairs Review, 8(3), 283-288.

7. Williams, P. D. (2007). Thinking about security in Africa. International Affairs, 83(6), 1021-1038.

8. Wisler, D. (2007). The International Civilian Police Mission in Bosnia and Herzegovina: from democratization to nation-building. Police Practice and Research, 8(3), 253-268. 